$\S=$ 茞

\title{
Biogas production from blends of fonio husk and donkey dung via anaerobic digestion for sustainable development
}

\author{
Ogala Harrison $^{1}$, Ige Ayodeji Rapheal ${ }^{2}$ \\ ${ }^{1}$ Department of Chemical Science, Admilralty University of Nigeria. Asaba, Delta State, Nigeria \\ ${ }^{2}$ Department of Pure and Applied Chemistry, Kebbi State University of Science and Technology, Aliero, Nigeria \\ *Corresponding author E-mail: ogalaharrison@gmail.com
}

\begin{abstract}
There is growing public concern over potential impact on environmental quality caused by animal wastes. Anaerobic digestion, a biological conversion process can be used to obtain energy from biologicall wastes. This study explored the production of biogas from co-digestion of fonio hus and donkey dung using anaerobic biological conversion. The digesters were labeled as; digester A -Fonio husk only, digester B - donkey dung only, digester C - Fonio husk (300g) and Donkey Dung (200g), digester D - Fonio husk (200g) and donkey dung $(300 \mathrm{~g})$. Proximate analysis of the substrates before and after digestion were determined such as total solids (TS), volatile solid, carbon content, nitrogen content, ash content, etc., and $\mathrm{pH}$ before and after digestion process. The biogas produced during this period was collected by water displacement method and subsequently measured. The results showed that Fonio husk in bio-digesters A and B gave a cumulative average biogas volume of $4972 \mathrm{ml}$ and $5222 \mathrm{ml}$ (week 3) while pig dung in bio-digesters C and D gave a cumulative average biogas volume of $5564 \mathrm{ml}$ and 5978 respectively (week 3) within three weeks of fermentation. The digester is capable of producing $0.007 \mathrm{~m}$ at average working temperature of $320 \mathrm{C}$. Digester D produces higher volume of biogas as a result of improved nutrient provide by donkey dung as shown in the results obtained from the proximate analysis and has the best neutral $\mathrm{pH}$, there was a reduction in the startup time.
\end{abstract}

Keywords: Biogas; Digester; Production; Dung; Temperature.

\section{Introduction}

In Nigeria, agricultural waste generation is raising fast and creating humongous wastes disposal and management difficulties. The very reason is the population increment and cities' expansion (Ojolo et al., 2007). As the need for energy by man is excessively increasing and there has been an unrelenting search for the distinct forms of energy that will meet up with this energy need (Ofoefule et al., 2009). Biomass is an organic matter that is procured from plants, cereals, algae, animal wastes. It is plentifully obtainable due to its accessibility and also that carbon generated is harmless. It is made up of three main parts which are cellulose, hemicelluloses and lignin (Ige et al., 2020).

Biogas can be generated by anaerobic digestion with anaerobic organisms, which digest material inside a closed system, or fermentation of biodegradable materials. Biogas is composed of methane $\left(\mathrm{CH}_{4}\right)$ and carbon dioxide $\left(\mathrm{CO}_{2}\right)$ and may have small amounts of hydrogen sulfide, moisture and siloxanes (Okolie et al., 2017). The gases methane, hydrogen, and carbon monoxide (CO) can be burnt or oxidized with oxygen. This energy release allows biogas to be used as a fuel; it can be used for any heating purpose, such as cooking. It can also be used in a gas engine to convert the energy in the gas into electricity and heat (Okolie et al., 2017).

Fonio husk is a cereal, which is surrounded by an outer protective covering or the husk like rice (Ballogou et al., 2013). After harvest, the husk is often heaped up to constitute environmental nuisance. This is often the case with post-harvest Agricultural wastes (Ndububa et al., 2016). The utilization of fonio husk for the production of biogas was not very much studied. Agricultural wastes such fonio husk and donkey dung can be transformed into valuable products via anaerobic digestion which provide vital substitute sources of energy for domestic use and small industrial scale. Transforming biomass into biogas through biological conversion aids in eliminating wastes and also makes the environment clean from unacceptable wastes (Ige et al., 2018). It also diminishes greenhouse gas emissions and to attain alternative livelihood to the urban and rural communities (Banconguis, 2007). The selection of the above-mentioned agricultural wastes is owing to the fact that such materials are readily available in abundance at North-West region of Nigeria

Therefore, the focus of this study is to investigate the production of biogas from fonio husk and donkey dung, as a potential alternative source of energy. The objectives of the research were to investigate the effect of the nature of both fonio husk and donkey dung and their co-digestion, on biogas production yield. 


\section{Materials and methods}

The materials used were fonio husk and donkey dungs. The samples were collected in Koko and Aliero towns, Kebbi State, and Northwestern Nigeria. The fonio husks were sun dried for two weeks while the dungs were sun dried for 2-3 days and grounded using mortar and pestle. The dried pulverized samples were stored in tight containers until further analysis.

\subsection{Substrates analysis}

Proximate analysis of these substrates was carried out to determine their Total solids (TS), voluble solid (VS), carbon content, nitrogen content, ash content, moisture content, nitrogen/carbon ratio $(\mathrm{C}: \mathrm{N})$ ratio and $\mathrm{pH}$ before and after digestion process.

\subsubsection{Total solids (TS)}

These are the sums of suspended solids and dissolved solids. The total solids are composed of two components, Volatile Solid (VS) and Fixed Solid. This was calculated using equation in equation (1) (Ukpabi et al., 2017).

Total Solid $\%=\frac{\mathrm{A}-\mathrm{B}}{\mathrm{D}-\mathrm{B}} \times 100$

Where $\mathrm{A}=$ weight of dish + dried sample at $75^{\circ} \mathrm{c}(\mathrm{g}), \mathrm{B}=$ weight of dish $(\mathrm{g}), \mathrm{C}=$ weight of dish + sample after ignition at $550^{\circ} \mathrm{C}(\mathrm{g})$ and $\mathrm{D}=$ weight of dish + wet sample $(\mathrm{g})$.

\subsubsection{Volatile solids (VS)}

The VS are organic portion of TS that biodegradable anaerobically. This parameter was calculated using equation (2) (Ukpabi et al 2017)

Volatile Solid $\%=\frac{\mathrm{A}-\mathrm{C}}{\mathrm{A}-\mathrm{B}} \times 100$

Where $\mathrm{A}=$ weight of dish + dried sample at $75^{\circ} \mathrm{c}(\mathrm{g}), \mathrm{B}=$ weight of dish $(\mathrm{g}), \mathrm{C}=$ weight of dish + sample after ignition at $550^{\circ} \mathrm{C}(\mathrm{g})$ and $\mathrm{D}=$ weight of dish + wet sample $(\mathrm{g})$.

\subsubsection{Determination of moisture content}

The determination was carried out for both substrates and digestates. For all samples, clean and dry Petri dish was weighed ( $\left.\mathrm{W}_{0}\right)$. $2.0 \mathrm{~g}$ of each sample was taken and placed in the Petri dish such that the total weight of the loaded sample dish would be ( $\left.\mathrm{W}_{\mathrm{b}}\right)$. The loaded dish was then placed in Gallen Kamp Oven and adjusted to a constant temperature of $105^{\circ} \mathrm{c}$ for 24 hours. The dish will then be removed from the oven and placed in the desiccators to cool. When it cooled, the dish with its content was weighed, to obtained ( $\left.\mathrm{W}_{\mathrm{a}}\right)$. The moisture content was evaluated using the equation (3) as reported by Ukpabi et al (2017).

$\%$ Moisture $=\frac{\mathrm{W}_{\mathrm{b}}-\mathrm{W}_{\mathrm{a}}}{\mathrm{w}_{\mathrm{s}}} \times 100$

Where $\mathrm{W}_{\mathrm{b}}=$ Mass of sample and dish before drying

$\mathrm{W}_{\mathrm{a}}=$ Mass of sample and dish after drying

$\mathrm{W}_{\mathrm{s}}=$ Mass of the sample taken

\subsubsection{Determination of ash content}

This was carried out for both substrates and digesters. Porcelain crucibles was washed and dried for each sample and weighed as ( $\left.\mathrm{W}_{1}\right)$. $\mathrm{A}$ $2.0 \mathrm{~g}$ of respective sample was weighed into crucible as $\left(\mathrm{W}_{2}\right)$ and placed in lenthon furnace and was heated at $600^{\circ} \mathrm{C}$ for 3 hours.

The furnace was switched off and then allows the crucible to cool. Thereafter, the sample was removed from the furnace and placed in desiccators to further cool down at room temperature. This was reweighed to obtain $\left(\mathrm{W}_{3}\right)$. The percentage ash content was calculated using the following equation (4) as reported by Ukpabi et al (2017).

Ash Content $\%=\frac{\mathrm{W}_{2-} \mathrm{W}_{3-}}{\mathrm{W}_{2}} \times 100$

Where $\mathrm{AC}=$ Ash Content

$\mathrm{W}_{3}=$ Weight of crucible and sample after heating

$\mathrm{W}_{2}=$ Weight of crucible and sample before heating

\subsubsection{Determination of total carbon}

Total carbon was determined according to AOAC, (2000) procedure.

\subsubsection{Determination of total nitrogen}

Two grams of each powdered sample in an Ash fewer filter was dropped into $500 \mathrm{~cm}^{3}$ kjeldahl flask. Three grams of digesting catalyst (selenium) and $10 \mathrm{ml}$ conc. $\mathrm{H}_{2} \mathrm{SO}_{4}$ was also dropped into the kjedahl flask. The sample was digesting until a clear green colour is obtained. The digestion was allowed to cool and was diluted into $100 \mathrm{ml}$ with distilled water. $20 \mathrm{ml}$ of diluted digest was measured into $500 \mathrm{ml} \mathrm{kjeldahl} \mathrm{flask} \mathrm{containing} \mathrm{ant-bumping} \mathrm{chips} \mathrm{and} 40 \mathrm{ml}$ of $40 \% \mathrm{NaOH}$ was slowly added by the side of the flask. A $250 \mathrm{ml}$ conical flask containing a mixture of $50 \mathrm{ml} 20 \%$ boric acid and 4 drops of mixed indicators was used to trap the ammonia being liberated. The conical flask and the kjeldahl flask were then placed on the kjeldahl distillation apparatus with the tubes inserted into the conical flask 
and kjedahl flask. The flask was heated to distil out the $\mathrm{NH}_{3}$ evolved. The distillate was collected into the boric acid solution, when the boric acid turned green, it was allowed for 10 minutes to complete distillation of the ammonia present in the digest. The distillate was then titrated with $0.1 \mathrm{M} \mathrm{HCl} \mathrm{AOAC,} \mathrm{(2000).}$

$\%$ Nitrogen $\mathrm{N}_{2}=\frac{14 \times \mathrm{M} \times \mathrm{Vt} \times \mathrm{TV}}{\text { weight of sample }} \times 100$

Where $\mathrm{M}=$ Actual Molarity of Acid

$\mathrm{TV}=$ Titre Volume of $\mathrm{HCl}$ used

$\mathrm{Vt}=$ Total Volume of Diluted Digester

\subsection{Fermentation of the slurry}

Preparation of fermentation slurry was done by addition and vigorous mixing of total solid with an equivalent amount of water needed for maximum yield. The water content for each sample was determined using the recommendation for better biogas production as reported by Ituen et al,. (2007), that is, a total solid (TS) of $8 \%$ in the fermentation slurry. This was the basis for the determination of the amount of water to be added for any given mass of total solid. Hence, the proportion of total solid in the slurries was the same in all the digesters

The $\mathrm{pH}$ of the slurry was measured before and after digestion.

Table 1: The Procedures Taken During Mounting of the Digesters Are As Follows:

\begin{tabular}{lll} 
& Table 1: The Procedures Taken During Mounting of the Digesters Are As Follows; & Volume of water (litres) \\
\hline Digesters & Content (gram) & $3000 \mathrm{mls}$ \\
Digester A & A (500g) & $4000 \mathrm{mls}$ \\
Digester B & B (500g) & $3200 \mathrm{mls}$ \\
Digester C & C (300g and 200g) & $3600 \mathrm{mls}$ \\
Digester D & D (200g and 300g) \\
\hline
\end{tabular}

\subsection{Experimental design}

A hole was bored on the lid of the can by a machine (chissle). One end of the hose pipe (which served as a delivery tube for the gas) was inserted into the hole bored on the lid, epoxy steel gum was then applied around the hole to ensure that no air seep into or out of the digester.

The samples (slurry) were then feed into the digester (Can) and then were covered with the lid which has already been connected to the hose pipe. Gum was applied around the circumference of the can lid to ensure an airtight condition which is necessary for anaerobic digestion.

The plastic bowls was filled with water and measuring cylinder containing water was then inserted into the plastic bowls filled with water avoiding bubbles of air. The retort stand was used to hold the measuring cylinder vertically in the bowls. The other end of the hose pipe was introduced into the water basin and passed through the measuring cylinder for the collection of gas produced. The volume of the water displaced is proportional to the volume of biogas generated.

The mode of loading was a discontinued feeding (batch feeding). This simply means loading the digester was at once and maintaining a closed environment throughout the retention period. Four different digesters were prepared for loading as shown in Figure 1. These digesters were labeled as follows:

Digester A -Fonio Husk only

Digester B - Donkey Dung only

Digester C - Fonio Husk (300g) and Donkey Dung (200g)

Digester D - Fonio Husk (200g) and Donkey Dung (300g)

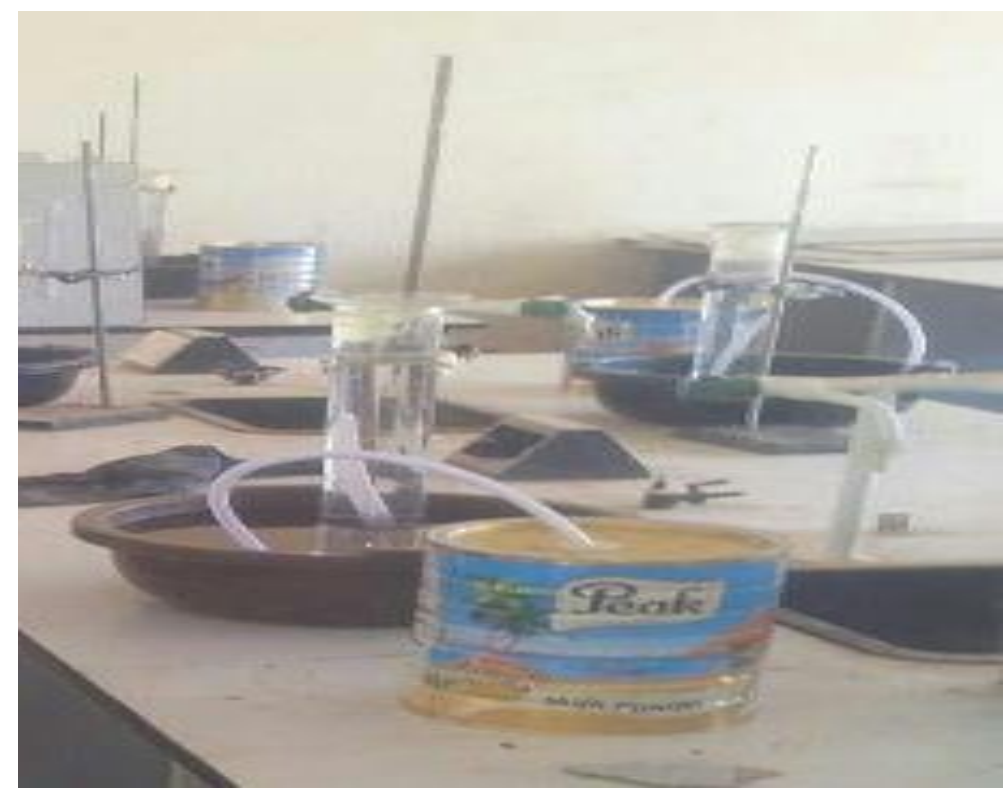

Fig. 1: Biogas Production Set-Up (Taken by the Authors). 


\section{Results}

Table 2: Proximate Analysis of the Substrate before Anaerobic Co-Digestion

\begin{tabular}{lll}
\hline PARAMETERS & SUBSTRATE A & SUBSTRATE B \\
\hline Total Solid (mg/l) & 83.5 & 65.2 \\
Volatile Solid (mg/l) & 33.8 & 43.0 \\
Total Nitogen (\%) & 6.0 & 32.5 \\
Total Carbon (\%) & 7.2 & 11.4 \\
Ash Content (\%) & 23.0 & 45.2 \\
Moisture Content $(\%)$ & 15.4 & 21.7 \\
\hline
\end{tabular}

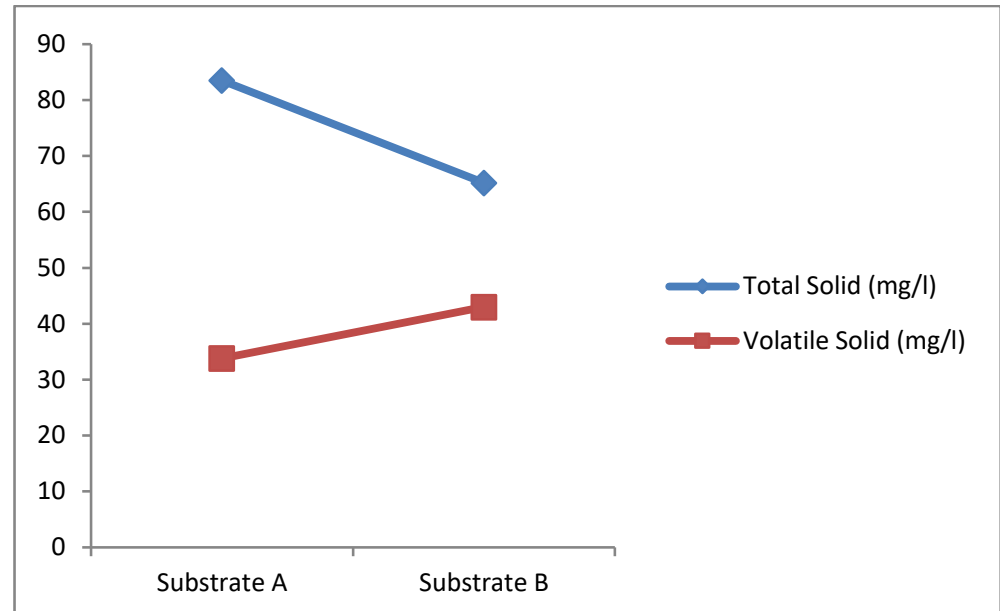

Fig. 2: Graph of Total Solid and Volatile Solid of the Substrates before Digestion (Taken by the authors).

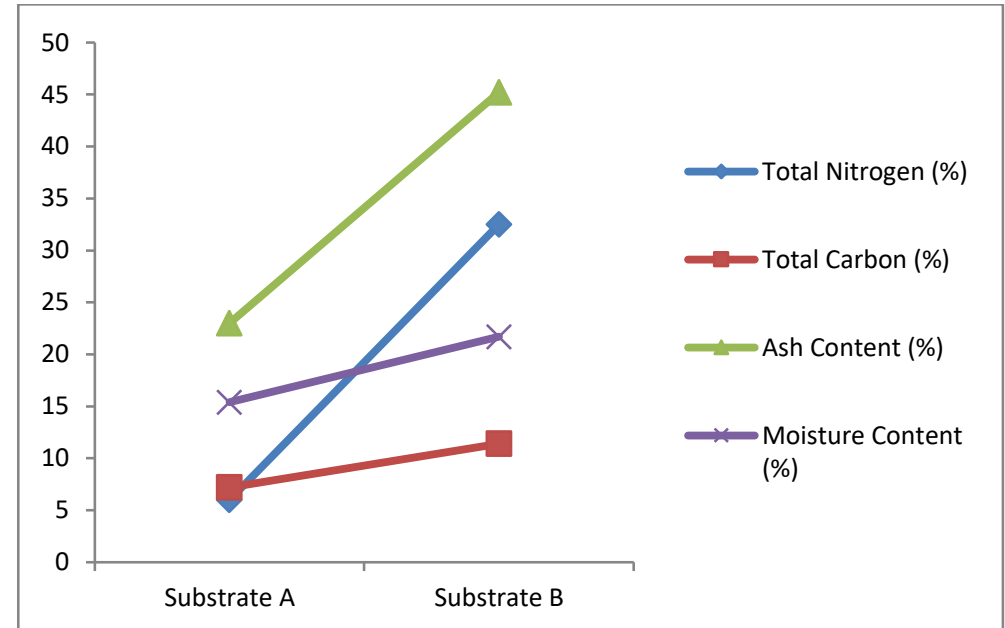

Fig. 3: Graph of Total Nitrogen, Total Carbon, Ash Content and Moisture Content before Digestion (Taken by the authors).

Table 3: Result of Proximate Analysis of the Digestate after Anaerobic Digestion

\begin{tabular}{|c|c|c|c|c|}
\hline Parameters & Digester A & Digester B & Digester C & Digester D \\
\hline Total solids (mg/l) & 65.00 & 52.50 & 62.10 & 56.00 \\
\hline Volatile solids (mg/l) & 26.00 & 34.50 & 27.50 & 29.00 \\
\hline Total carbon $(\%)$ & 6.00 & 7.00 & 1.93 & 2.23 \\
\hline Total nitrogen $(\%)$ & 4.50 & 11.40 & 1.21 & 1.79 \\
\hline Ash content $(\%)$ & 14.50 & 18.50 & 3.50 & 8.50 \\
\hline Moisture content (\%) & 2.00 & 6.00 & 5.00 & 4.50 \\
\hline
\end{tabular}




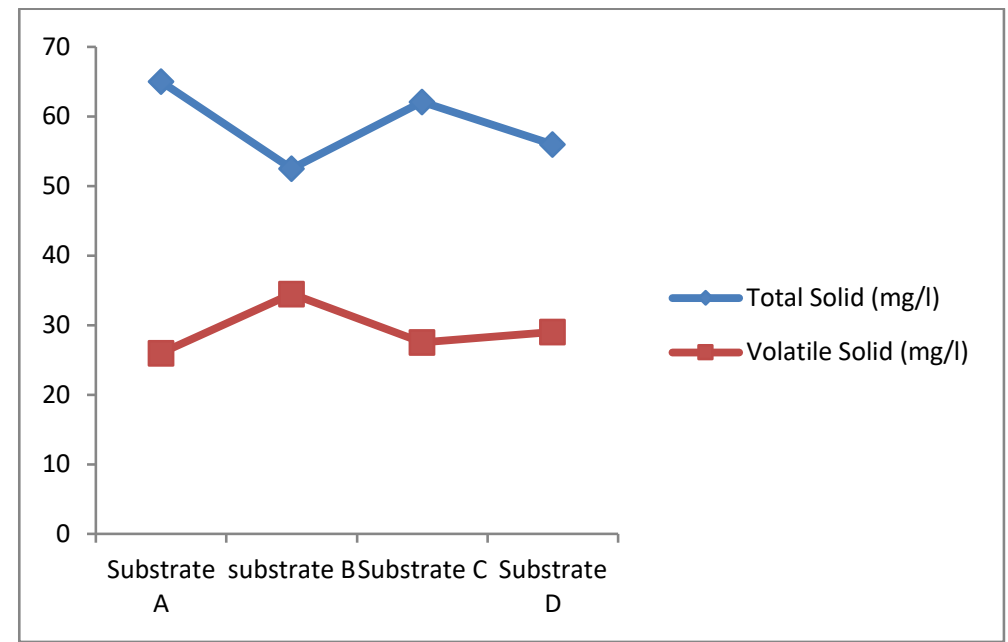

Fig. 4: Graph of Total Solid and Volatile Solid of the Substrates after Digestion (Taken by the authors).

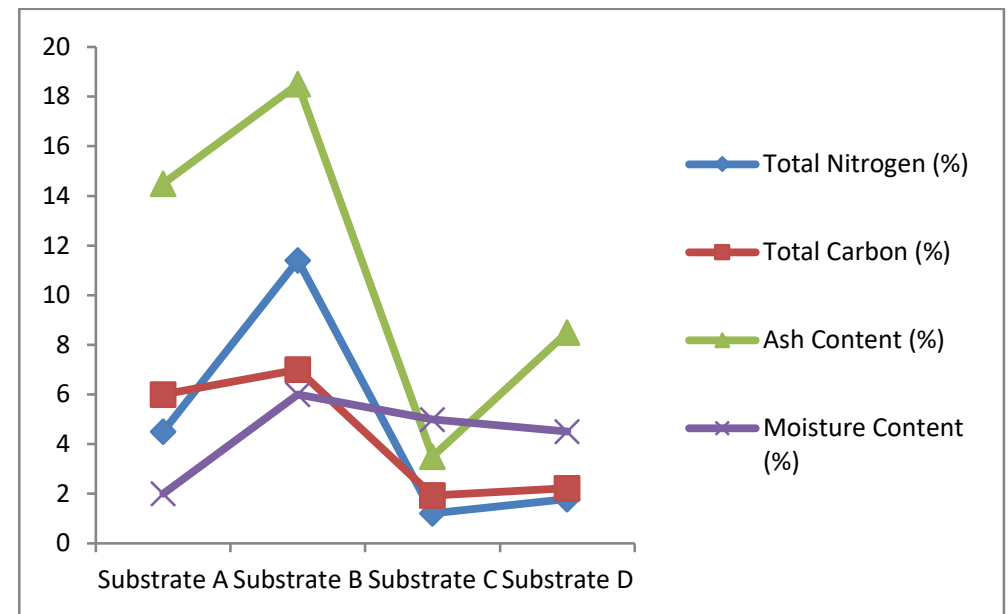

Fig. 5: Graph of Total Nitrogen, Total Carbon, Ash Content and Moisture Content after Digestion (Taken by the authors).

Table 4: Result of PH of the Slurries and Digestate Before and After Anaerobic Digestion

\begin{tabular}{lllll}
\hline PH & Digester A & Digester B & Digester C & Digester D \\
\hline Before & 8.20 & 9.50 & 8.70 & 9.10 \\
After & $4 . .4$ & 6.9 & 5.10 & 5.60 \\
\hline
\end{tabular}

Table 5: Result of Cumulative Weekly Biogas Production with Temperature for the Four Digesters

\begin{tabular}{llllll}
\multicolumn{7}{c}{ Table 5: Result of Cumulative Weekly Biogas Production with Temperature for the Four Digesters } \\
\hline Time (weeks) & Temperature $\left({ }^{\circ} \mathrm{C}\right)$ & Digester A $(\mathrm{ml})$ & Digester B $(\mathrm{ml})$ & Digester C $(\mathrm{ml})$ & Digester D $(\mathrm{ml})$ \\
\hline 1 & 32 & 372 & 152 & 1871 & 412 \\
2 & 32 & 2770 & 2620 & 4534 & 4724 \\
3 & 32 & 4972 & 5222 & 5564 & 5978 \\
4 & 34 & 3564 & 3675 & 4698 & 4998 \\
5 & 32 & 4100 & 3573 & 3290 & 5458 \\
\hline
\end{tabular}

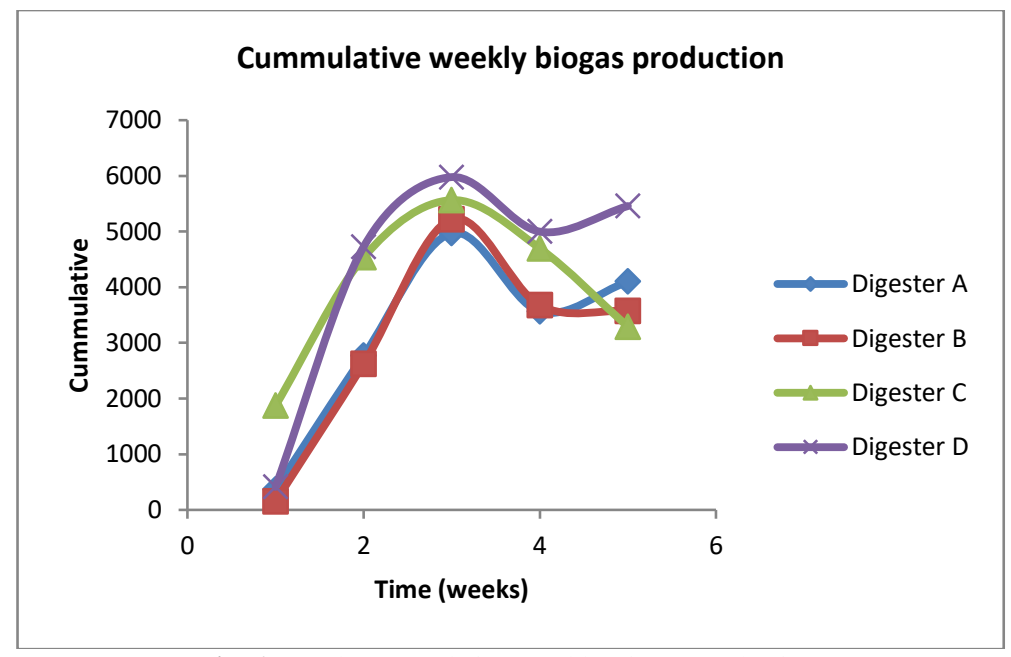

Fig. 6: Graph Cummulative Weekly Biogas Production. 


\section{Discussion}

The results of total solid (TS) for the sample A and B before digestion were $85.50 \%$ and $65.20 \%$ respectively as shown in Table 1 . After the anaerobic digestion, there was a decrease in the values of total solid for the two substrates as shown in Figure 2 and 4 . The values are $65.0 \%$ and $52.5 \%$ respectively for digester $\mathrm{A}$ and $\mathrm{B}$ and compare well with the result of $8.00 \mathrm{mg} / \mathrm{l}$ and $4.32 \mathrm{mg} / \mathrm{l}$ for rice husk before and after reported by Ezekoye et al., (2014). Digester C and D have the following values $62.1 \%$ and $56.0 \%$ respectively.

After the anaerobic digestion, there was a decrease in the result of the volatile solid for the two digesters. The values are $26.00 \%$ and $34.50 \%$ for digester A and B respectively. The values for digester C and D are $27.50 \%$ and $29.00 \%$ respectively as shown in Figure 2 and 4 . The increase in the values is as a result of the high volatile solid that has been converted to biogas. The results obtained are greater than $16.95 \%$ and lower than $81.20 \%$ of cow manure and garden waste respectively as reported by Spyridon and Gerrit, (2019).

There was a decrease in the value of total nitrogen in the samples as a result of the bacteria that have utilized the nitrogen for their metamorphic growth process as shown in Figure 2 and 4. After the anaerobic digestion, the values of Ash content were 14.5\% and 18.5\% for digester A and B respectively and it is compare well with the results obtained for cow dung and fowl dung $10.10 \%$ and $16.40 \%$ respectively as reported by Ukpabi et al., (2017). Digester C and D have the following values 3.5\% and 8.5\% respectively.

Substrate A has the higher moisture content before digestion. After the anaerobic digestion, the values of moisture content were 2.0 and 6.0 for digester A and B respectively Digester C and D have the following values 5.0 and 4.5 respectively.

$\mathrm{pH}$ is an important factor that affects anaerobic digestion as reported by Spyridon and Gerrit, (2019), the values of the $\mathrm{pH}$ before the anaerobic digestion of the four(4) slurries are 8.20, 9.250, 8.70 and 9.10 for digester A,B,C and D respectively. It has been reported that anaerobic bacteria required a neutral environment and thus a $\mathrm{pH}$ ranging from 6.4-7.2 is needed for optimum biogas production (Spyridon and Gerrit, 2019). There was a decrease in the $\mathrm{pH}$ of the digestate after the anaerobic digestion.

After the anaerobic digestion, the values of total carbon were 6.0 and 7.0 for substrate A and B respectively. Digester C and D have the following values 1.93 and 2.23 respectively. There was a decrease in the values; this might be as a result of biogas formation (Aremu and Agarry, 2012).

It has been noted that temperature and retention time are among the parameters that influence anaerobic fermentation of organic matter. From figure 6 , it can be observed that from retention time (RT) interval between 0 week and 1 week, the rate of production of biogas was almost constant. Between about 1 wee and 3 weeks, the rate of generation of the gas was increased.

The temperature range throughout the retention periods is within $32-34^{\circ} \mathrm{C}$ which is optimum for biogas production under mesophilic condition. This also validate the temperature range cited by oyeleke (2007), at low temperature, microorganism become inactive and rate of gas production drops but resumes when the temperature is favorable.

Digester D (fonio husk and donkey dung 300g and 200g); the production began on the 3rd day of the retention period by producing $40 \mathrm{mls}$ of biogas. The highest production was recorded on the 3rd with the value of $5978 \mathrm{ml}$. Digester D produces higher volume of biogas compared to digester B. This was as the result of improved nutrient provided by donkey dung based on the result of the proximate analysis obtained before digestion.

\section{Conclusion}

The proximate analysis had been conducted to show the characteristics of fonio husk and donkey dung to become biogas via data of total solid, volatile matter, moisture, ash content etc.

Digester D recorded the highest experimental daily biogas volume on the third week of the digestion process. Digester D produces higher volume of biogas. This was as the result of improved nutrient provided by donkey dung and has the best neutral pH. Biogas production from anaerobic co-digestion of fonio husk and donkey dungs was established in this research work to be feasible of mesophilic temperature range $\left(32-40^{\circ} \mathrm{C}\right)$ and this gives positive attribute towards a search for sustainable renewable energy source (SRES).

\section{References}

[1] AOAC (2000). Official Methods of Analysis: Association of Analytical Chemists, Gaithersburg, MD, USA. Methods 952.10, 65.17, 974.24, 992.16.

[2] Aremu, M .O. \&Agarry S. E,(2012) Comparison of Biogas production from cow dung and pig dung under mesophilic condition, International Refereed journal of Engineering and science (IRJES) ISSN (Online) 2319- 183X,(Print) 2319-1821 Volume 1,Issue 4 (December 2012), PP, 16-21

[3] Ballogou Vénérande Y, Soumanou Mohamed M, Toukourou Fatiou and Hounhouigan Joseph D (2013). Structure and Nutritional Composition of Fonio (Digitaria exilis) Grains: A Review International Research Journal of Biological Sciences. Vol. 2(1), 73-79.

[4] Banconguis, S. R. (2007). Abandoned biomass resource statistics in Philippines. Paper presentedduring the $10^{\text {th }}$ National Convention of statistics Momila, Phillippines. October, 2007.

[5] Ige A. R, Elinge C. M, Hassan L. G, Adegoke I. A, and Ogala H (2018). Effect of Binder on Physicochemical Properties of Fuel Briquettes Produced from Watermelon Peels. AASCIT Journal of Energy. Vol. 5, No. 2, 2018, pp. 23-27.

[6] Ige, A. R., Elinge, C. M., Aliyu, M., Gwani, M., \& Hassan, L. G. (2020). Optimization and characterization of bio-oil produced from rice husk using surface response methodology. Acta Chemica Malaysia, 5(1), 10-17. https://doi.org/10.2478/acmy-2021-0003.

[7] Ituen E.E, John N.M, Bassey B.E (2007). Biogas Production from Organic Waste in Akwa Ibom State of Nigeria. Appropriate Technologies for Environmental Protection in the Developing World. Selected Papers from ERTEP 2007, Pp.17-19.

[8] Ndububa E.E, Okonkwo J.S and Ndububa O.I (2016). The Potential Use of Fonio Husk Ash as a Pozzolana in Concrete. Nigerian Journal of Technology (Nijotech) Vol. 35, No. 1, January 2016, Pp. 31 - 36. https://doi.org/10.4314/njt.v35i1.5.

[9] Ofoefule, Akuzuo U., Uzodinma E.O and Onukwuli O.D (2009). Comparative Study of the Effect of Different Pre-treatment Methods on Biogas Yield from Water Hyacinth (Eichornia crassipes). International Journal of Physical Sciences, 2009; 4(8): 535-539.

[10] Ojolo S. J, Dinrifo R. R, Adesuyi K. B (2007).Comparative study of biogas production from five substrates. Advanced Materials Research. 2007; 18(19):519-525. From five substrates. Advanced Materials Research. 2007; 18(19):519-525. https://doi.org/10.4028/www.scientific.net/AMR.1819.519.

[11] Okolie, N. P., Onifade, A.K., Oladunmoye M. K., Adegunloye, D. V. Study On the Biogas Yielding Potential of a Portable Bioreactor Using a Blend of Corn Cob and Rice Chaff Mixed with Goat and Dog Dungs. IOSR Journal of Environmental Science, Toxicology and Food Technology (IOSR-JESTFT) e-ISSN: 2319-2402,p- ISSN: 2319-2399.Volume 11, Issue 6 Ver. III (June. 2017), PP 56-63 https://doi.org/10.9790/24021106035663 .

[12] Oyeleke, S.B (2007). Microbe and Bioenergy Production. Paper Presented at $31^{\text {st }}$ Annual Conference of Nigerian Society of Microbiologist held at Faculty of Science Usmanu Danfodiyo University, Sokoto, Pp. 1-27. 
[13] Ezekoye, V. A, Onah, D. U, Offor, P. O and B. A. Ezekoye (2014). Characterization of Biogas Produced from Rice Husks and Algae using a Metal Fixed-Dome Biodigester. Global Journal of Science Frontier Research: G Bio-Tech \& Genetics Volume 14 Issue 1, Pp: 1-10, 2014

[14] Spyridon A and Gerrit J.W. E (2019). Elevated biogas production from the anaerobic co-digestion of farmhouse waste: Insight into the process performance and kinetics. Waste Management \& Research 2019, Vol. 37(12) 1240- 1249. https://doi.org/10.1177/0734242X19873383.

[15] Ukpabi Chibueze F, Agbafor Kingsley N, Ndukwe Okorie K, Agwu Akuagwu, and Nwachukwu Success (2012). Phytochemical composition of Costus afer extract and its alleviation of carbon tetrachloride -induced Hepatic oxidative stress and toxicity. International Journal of Modern Botany 2012; 2(5)120-126. https://doi.org/10.5923/j.ijmb.20120205.01.

[16] Ukpabi Chibueze F.1, Ntiwunka Okechukwu K., Emole Eke C., Ndulaka J, Nwachukwu I, Esenamunjor C (2017). Biogas Production from Blends of Cow and Fowl Dung Using Locally made Anaerobic Digester. Energy and Power 2017, 7(2): 37-40. 